\section{Watson and DNA: Making a Scientific Revolution} perienced science writer.

\author{
By Victor K. McElheny \\ Perseus Publishing \\ $400 \mathrm{pp}, \$ 27.50,2002$
}

\section{REviEWED BY JUdAH FOLKMAN \\ Children's Hospital and Harvard Medical School Boston, Massachusetts, USA}

It is rare that a scholarly biography is a real page-turner. Victor McElheny has written a brilliant life story of James Watson, coinciding with the fiftieth anniversary of the discovery of the structure of DNA by Watson and Francis Crick. The story of the most significant biological discovery of the twentieth century has been told in many venues, but McElheny brings a fresh perspective from his unique vantage point as an ex-

McElheny's book takes us from Watson's formative years in Chicago, where as a youth he was influenced by Sinclair Lewis' Arrowsmith, to the University of Chicago, where he learned the importance of theory in science and the value of thinking versus memorization and, after reading Erwin Schrödinger's What is Life, realized that genes must be the key components of living cells. We see how Watson's thinking was focused by his graduate studies in genetics at Indiana University with Salvador Luria and by his summers at Cold Spring Harbor Laboratory with Max Delbrück. McElheny adroitly describes this journey toward the structure of DNA and its culmination in the famous Watson-Crick model on February 28, 1953.

Since this discovery, after which most scientists would have retired in self-satisfaction, Watson continues to lead a profound revolution in biology. After a brief sojourn at Caltech with Delbrück and George Beadle, Watson joined the Harvard faculty and opened a fault line between traditional biology and the young science of molecular biology. He attracted the best students and colleagues, some of whom have won Nobel Prizes, and wrote two seminal and remarkably influential books. He explained, in a wonderfully conceptual style, the basis of the new field of molecular biology in his textbook, The Molecular Biology of the Gene, and demolished the public's naive view of how science is done with his irreverent account of discovery in The Double Helix. He became director of the Cold Spring Harbor Laboratory and, together with his wife Elizabeth, built it into a world-class research institute. Watson went on to use the extraordinary scientific leadership, fund-raising skills and political acuity he acquired as director to spearhead the plan to sequence the human genome through its initial opposition, and then to serve as inaugural director of the Human Genome Project.

Throughout the book, McElheny documents Watson's uncanny ability to identify fundamentally important problems in science and to avoid trivial research. Watson's ability to immediately see a paradigm among a profusion of facts is unparalleled, in my experience. I came to personally appreciate his intuition and vision about the importance of angiogenesis in cancer. But seeing so vividly what others don't, or seeing too long before others do, can cause trouble for the visionary. Jim Watson is no stranger to this dilemma, as he communicates his visions with the bluntness of the child who observed that 'the emperor has no clothes.' Nevertheless, scientists who

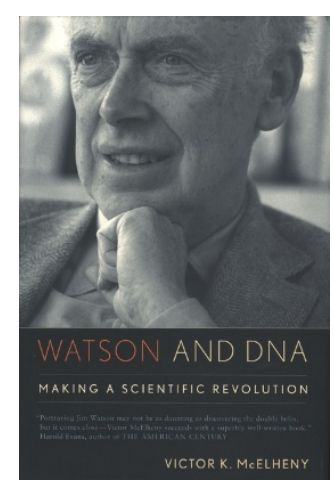

solve a jigsaw puzzle even when the best solid evidence had been ignored."

- There is value in scientific partnerships of equals.

- "Two people are better than one. Otherwise you get in a rut, you can get too fond of your own ideas, you get the wrong idea, you can't get out of it."

- Young scientists who feel the need to assert their independence should not do it by cloistering themselves.

- "Rosalind Franklin just needed a collaborator. She didn't have somebody to break the pattern of her thinking."

- Above all, find the best mentor.

One of Watson's major and unheralded contributions to science has been the generations of world-class scientists he has mentored by guiding, cajoling, criticizing and inspiring them to unprecedented successes and extraordinary contributions to our knowledge of biology.

Watson let his students work for themselves, took his name off their papers and did not check on them daily. He loaded them with credit, pushed them toward almost impossible-tosolve problems and steered them away from safe subjects. He encouraged intense interactions in the laboratory and made sure that their results were communicated clearly, freely and quickly. He saw this as a way to develop their selfstretch boundaries, who overturn conventional wisdom and provoke colleagues to escape from old ideas, require "boldness that may appear to be impudence," to paraphrase Robert Merton.

Scientific research is fraught with failure, not unlike other careers that depend on creativity. Embedded in this biography are gems of wisdom from Watson and his colleagues that should guide young scientists in all fields on how to be the best that one can and how to learn from failures. Some of his most poignant examples:

- Conventional wisdom is often wrong. - Take real joy in the discoveries of others; what matters most is whether the result is important.

- "Jim and Francis believed that in order to go fast, you must share information in the expectation of learning things, rather than withhold it from fear of theft."

- Sometimes, "a beautiful insight could confidence early on, and later, their independence. Watson taught his students that in stumbling toward some basic insight, the young researcher must be willing to put in years of obsessive effort and put up with surprises, upsets, reversals, relentless skepticism from colleagues, endless abandonment of cherished hypotheses, mistakes and failure. must be searched for a telling detail, and people in many disciplines must be questioned or recruited into collaborations. Finally, in choosing a field of research, one with a big, important question surrounded by a few facts is often a better choice than a field of many facts without an interesting paradigm.

For these lessons alone, Watson and $D N A$ is an invaluable guide for young scientists and their mentors. If Victor McElheny is not already a prince among science writers, this book should elevate him to that high position. Equipment must be adapted, literature 